\title{
THE DETERMINANTS OF ACCESS TO ADOLESCENT- FRIENDLY HEALTH SERVICE: A CASE CONTROL STUDY
}

\author{
Determinan Akses Pelayanan Kesehatan Peduli Remaja: \\ Sebuah Studi Kasus Kontrol \\ *Izzatul Arifah', Lenni Ayu Kusumawardani', Dwi Hendriyaningsih', \\ Mukti Aji Wibisono', Estu Puji Lestari \\ ${ }^{1}$ Department of Public Health, Faculty of Health Sciences, Muhammadiyah Surakarta University, Indonesia \\ ${ }^{*}$ Correspondence: ia523@ums.ac.id
}

\begin{abstract}
Background: Adolescents need to access Adolescent-Friendly Health Service (AFHS) to get it's benefit in order to improve adolescent health. However, the current adolescent access to that service remains low with the access prevalence under $50 \%$ ).

Aim: This study determined factors that affected adolescents' access to AFHS.

Methods: This school-based case control study was conducted in 9 junior and senior high schools in the area of Sangkrah and Kratonan in Surakarta District. There were 162 cases (who accessed the AFHS by guidance from health professionals and peer educators) and 162 controls (those who did not) who were chosen using total sampling and proportionate random sampling technique, respectively. A multiple logistic regression analysis was used to assess the determinant factors of AFHS access.

Results: Access to AFHS was significantly determined by knowledge of the program and perceived demand. A probability of finding adolescents who had knowledge of the program was 6 times higher in the case group than in control group with the OR value of $6.1(95 \% \mathrm{Cl} 3.3-11.1)$.

Conclusion: Overall, the low adolescents' access was mostly caused because of insufficient knowledge. Broadening information about the program and adolescents' access to the program through electronic media and peer educators is required.
\end{abstract}

Keywords: access, adolescent, Adolescent-Friendly Health service, AFHS.

\section{ABSTRAK}

Latar Belakang: Remaja perlu mengakses program Pelayanan Kesehatan Ramah Remaja (PKPR) untuk mendapat manfaat program PKPR guna meningkatkan kesehatan remaja. Namun hingga kini akses remaja pada PKPR masih rendah dengan prevalensi kurang dari $50 \%$.

Tujuan: Penelitian ini menganalisis faktor determinan akses remaja pada PKPR.

Metode: Penelitian kasus control berbasis sekolah diselengggarakan oada 9 Sekolah (SMP dan SMA) di wilayah Sangkrah dan Kratonan Kota Surakarta.Terdapat 162 kasus (mengakses pelayanan PKPR melalui tenaga kesehatan dan atau konselor sebaya) dan 162 kontrol (tidak mengakses pelayanan PKPR) dipilih dengan teknik total sampling dan proportionate random sampling. Analisis multivariat dilakukan dengan uji multiple logistic regression.

Hasil: PKPR dipengaruhi oleh pengetahuan tentang layanan dan persepsi kebutuhan pada layanan PKPR. Peluang untuk menemukan remaja yang memiliki pengetahuan tentang layanan PKPR 6 kali lebih tinggi pada kelompok yang mengakses dibanding yang tidak dengan OR 6.1 (95\% Cl 3.3-11.1).

Kesimpulan: Rendahnya akses remaja pada layanan PKPR utamanya dipengaruhi oleh kurangnya pengetahuan tentang layanan. Perluasan informasi layanan dan kebutuhan remaja untuk mengakses layanan PKPR melalui media elektronik dan konselor sebaya diperlukan.

Kata kunci: akses, remaja, pelayanan kesehatan ramah remaja, PKPR.

\section{INTRODUCTION}

The World Health Organization recommended each country to organize
Adolescent-Friendly Health Service (AFHS) in meeting the special needs of adolescents for education and reproductive health care. This program 
was aimed to implement one of the International Conference for Population and Development (ICPD) Program of Action in 1994 (Sawyer et al., 2012; World Health Organization, 2012). The equitable and quality AFHS then became one of the priority agendas, especially in developing countries including Indonesia. The Indonesian Ministry of Health launched a Adolescent-Friendly Health Service program (AFHS) in primary healthcare centers. Within a decade and a half of the program were running, the number of primary healthcare centers conducting the AFHS has increased and spread fairly in various provinces. The data showed that $81.69 \%$ of the total districts in Indonesia had at least 4 primary healthcare centers with AFHS in 2014. This percentage represented about $31 \%$ of the total primary healthcare centers in Indonesia (Centre for Data and Information of Indonesian Ministry of Health, 2018).

Many other developing countries have provided AFHS in parimary healthcare centers as well, but the access to the program is still limited. Research on the quality assessment of AFHS in Southern Africa showed that there were no health facilities that met the minimum friendly adolescent health facility standards in two provinces studied (James et al., 2018). Another study on adolescents' access to AFHS in India showed that the program was limited to only a small proportion of female adolescents (Dixit et al., 2017). Meanwhile, studies in sub-country areas in Kenya and Ethiopia found only $38.5 \%$ and $36 \%$ of adolescents had respectively utilized AFHS even though improvements in adolescents' access to the program have been made, such as training peer educators from schools and organizing school-based reproductive health education programs (Motuma et al., 2016; Luvai et al., 2017).
The same issue occurred in Indonesia. The AFHS was designed to increase adolescent's access through school activities, youth activities in the community and other activities, and to form peer counsellors at schools (Situmorang, 2016). However, adolescents' access to the AFHS remains small. There was no national data available showing the number of adolescents who has accessed the program. Previous research in several districts and provinces showed that access to the AFHS was low. A study about the access to AFHS in South Kuta, Bali Province had only 5 visits per month in average (Winangsih, Kurniati and Duarsa, 2015). Several other studies found adolescents' access to the AFHSs ranged from $9.7 \%$ to $33.1 \%$ of the total adolescents in other Indonesian regions (Amieratunnisa and Indarjo, 2018; Handayani, 2016; Violita and Hadi, 2019; Sari et al., 2017). A pilot study in Surakarta City, Central Java Province showed the same result. There were only two regions which had fully implemented AFHS in Sangkrah and Kratonan Primary Healthcare Centers. However, the number of adolescents who have accessed to the AFHS was less than $5 \%$ of the total in the regions (Surakarta District Health Office, 2016).

Yet to improve adolescent health, the availability of AFHS alone is not enough. Adolescents need to access a reproductive health care centre (ChandraMouli, Lane and Wong, 2015). They may know references of sources of information and reproductive health care, promote safe sexual behaviour and have higher satisfaction and self-esteem regarding sexual health. With this expected behavior, they may reduce the burden of disease due to teenage pregnancy and childbirth throughout the world (Patton et al., 2009). In other cases, such access to the AFHS can prevent unsafe abortion and new HIV AIDS infections in adolescents. About $11 \%$ of teenage births were experienced by women aged 15-19 years per year; about $15 \%$ and $26 \%$ of unsafe abortion occurred to women aged 15-19 years and 20-24 years respectively (World Health Organization, 2018). Around 41\% 
of the total new HIV infections were found in adolescents aged 15 years and more often aged 15-24 years (UNICEF, 2011).

The availability of AFHS does not guarantee to decrease adolescents' reproductive health problems since adolescents might have troubles in accessing this program. Factors influencing adolescents' access to AFHS can be explained using demand and supply factors, as well as four dimensions of access namely physical accessibility, availability, affordability and acceptability (Jacobs et al., 2012). Various studies on the utilization of health services pointed out physical accessibility (distance and means of transportation to the health facilities that provide AFHS) was one of the determinants. A slight deviation in the research in Surakarta showed that this variable was difficult to measure because of rare direct access to the AFHS. Most of adolescents accessed AFHS when a health officer or peer educators visited their schools. Besides, affordability aspect was difficult to measure as well because the program did not charge all adolescents. Only few studies assessed factors influencing access to AFHS in Indonesia (Violita and Hadi, 2019). A qualitative approach to measure the access of AFHS is commonly in use because the prevalence of access to the program in Indonesia is small (Handayani, 2016; Friskarini and Manalu, 2016). In addition, this study was conducted in Surakarta district because it was declared as one of the child-friendly cities. Providing and implementing Adolescent-Friendly Health Service becomes the indicator of the city's success. Moreover, the AFHS in Surakarta have routinely been carried out through peer educator training in the target schools. Nevertheless, the prevalence of access was $5 \%$ of total adolescents in Surakarta district in 2015 (Surakarta District Health Office, 2016). Therefore, the researchers were interested in investigating the determinants of access to AFHS in Surakarta City using quantitative approach.

\section{METHOD}

A school-based case control study was conducted in 9 junior and senior high schools in total in the area of Sangkrah and Kratonan Primary Healthcare Centers in Surakarta District, Indonesia from January to May 2019. This study had an ethical approval from the Health Research Ethics Committee, Faculty of Medicine, Muhammadiyah Surakarta University (No.: 2105/B.1/KEPK-FKUMS/V/2019). A case control approach was chosen since the actual access to AFHS was limited at $5 \%$ of total adolescents in Surakarta district. This study obtained permits from the principles of 12 target junior and senior high schools in the working areas of Sangkrah and Kratonan Primary Healthcare Centers. Out of 2095 students in that schools who filled screening questionnaires, there were $15.8 \%$ students who utilized AFHS for receiving health information and health consultation from health professionals and peer educators at each school. A case group was those students who accessed the AFHS in 2017 and 2018 by guidance from either health professionals or peer educators and were confirmed by health professionals or peer educators. There were 174 identified cases, which of being confirmed were were included in this study. Finally, only 162 students signed a informed consent form. Consideration was not made based on adolescent's reproductive health in choosing the case group. A control group consisted of students who did not utilize AFHS to receive health information and health consultation from either health professionals or peer educators at the schools. The sampling technique for the control group were performed using proportionate random sampling. The ratio of case and control group was $n=1: 1$.

Eventually, the study obtained 162 students as the case group and 162 as the control group who then filled out a questionnaire about individual characteristics, knowledge of reproductive health, opportunity to access, knowledge, social perception, and perceived need for the AFHS. Independent variables included a combination of demand and supply factors, such as sex, knowledge, perceived needs, social perceptions of AFHS access, opportunity to access and 
knowledge of AFHS. Knowledge instrument consisted of 19 questions of basic reproductive health information. Respondents who were scored above the average of the total respondents' score were categorized as high knowledge. Leaving schools to access AFHS during school hours and not perceived time meant no opportunity access barrier. Respondents who regarded others' opinion and perceived that accessing AFHS was embarrassing and taboo, were categorized to have negative social perception. Knowledge of AFHS in this study was measured from whether the respondents knew, ever heard and got exposed to promotion agenda of AFHS. Additionally, perceived needs for AFHS were measured from 11 questions regarding needs and significance of reproductive health information and service and consultation session with health officers in 1 to 4 Likert scale. Respondents would be categorized based on the needs of AFHS if they had a total score of perceived needs above the average score of all respondents. All these instruments were self-designed and tested for validity and reliability. A multivariate analysis was deployed using multiple logistic regression with $95 \%$ confident interval.
In the case group, the respondents accessed the AFHS more from school's peer educators $(77 \%)$ than health professionals (23\%). Table 1 displays the respondent characteristics based on age, sex and level of education. Most of the respondents were senior high school students, which dominated the case group.

This study also found there was a difference in mean age, about 0.6 years higher in the case group than in the control one. The majority of the respondents were girl, but the proportion was slightly smaller in the control group. Overall, the respondents had slightly different characteristics probably due to the incompatible selection technique of the control group, which did not considered schools and grade.

Based on the independent variables, there were no significant differences in the proportion of knowledge about reproductive health in both groups. The number of respondents who had opportunity barrier was slightly greater than that who did not. Similarly, perceived demand on the service was experienced

\section{RESULTS AND DISCUSSION}

Table 1. Respondent Characteristics

\begin{tabular}{|c|c|c|c|c|c|}
\hline \multirow{2}{*}{$\begin{array}{c}\text { Respondent } \\
\text { Characteristics }\end{array}$} & \multicolumn{2}{|c|}{ Case } & \multicolumn{2}{|c|}{ Control } & \multirow{2}{*}{ P-Value } \\
\hline & $(n=162)$ & $(\%)$ & $(n=162)$ & $(\%)$ & \\
\hline \multicolumn{6}{|l|}{ Education level } \\
\hline Junior High School & 50 & 30.9 & 78 & 48.1 & 0.001 \\
\hline Senior High School & 112 & 69.1 & 84 & 51.9 & \\
\hline \multicolumn{6}{|l|}{ Sex } \\
\hline Male & 33 & 20.4 & 50 & 30.9 & 0.03 \\
\hline Female & 129 & 79.6 & 112 & 69.1 & \\
\hline \multicolumn{6}{|l|}{ Age } \\
\hline 12 & 0 & 0 & 3 & 1.8 & 0.006 \\
\hline 13 & 20 & 12.3 & 38 & 23.5 & \\
\hline 14 & 26 & 16.1 & 33 & 20.4 & \\
\hline 15 & 24 & 14.8 & 26 & 16 & \\
\hline 16 & 58 & 35.8 & 40 & 24.7 & \\
\hline 17 & 30 & 18.5 & 22 & 13.6 & \\
\hline 18 & 4 & 2.5 & 0 & 0 & \\
\hline Mean $\pm S D$ & & & 14. & .43 & \\
\hline
\end{tabular}


by a slight above half of the total respondents. Only about three quarter of the total respondents had negative social perception and knowledge of AFHS.

Bivariable analysis is explained in Table 2. Opportunity to access, perceived demand and sex were variables affecting the access to AFHS. The Odd Ratio (OR) for each variable was almost double to the female respondents who did not have opportunity barrier and perceived demand. The absence of social barrier signified from knowledge of the service had the highest OR value of $5.8,95 \% \mathrm{Cl}$ (3.2310.34).

The selection of variables in the final model for multivariable analysis was associated with the theory/literature review and multicollinearity between a group of independent variables. There was a significant association between sex and knowledge, in which girls knew the AFHS more than boys. Therefore, sex was excluded from the model because it could confound the variable of knowledge of
AFHS with access to AFHS. The effect of sex on the access to the AFHS was explained from the relation of knowledge of AFHS with access to AFHS. The selection of the final model was based on the value of AIC and Pseudo R2.

The final model in Table 3 was chosen because the AIC (Akaike Information Criterion) value was the smallest, and Pseudo R2 value was the highest. The probability to find respondents who knew AFHS was 6 times higher in the respondents with access with OR 6.2 95\% Cl (3.40- 11.34). Perceived need and opportunity to access affected the access with OR $1.9(95 \% \mathrm{Cl} 1.2-3.3)$ and $1.7(95 \% \mathrm{Cl} 1.06-2.8)$, respectively. It means the probability to find the respondents who perceived demand on the service and had an opportunity to access was double in the case group. The quality of the model in predicting AFHS access was seen from the pseudo R2 value of 0.124 . About $12.3 \%$ variation in

Table 2. Bivariable Analysis of AFHS Access in Surakarta District based on Independent Variables.

\begin{tabular}{|c|c|c|c|c|c|c|c|}
\hline \multirow{3}{*}{ Variable } & \multicolumn{4}{|c|}{ AFHS Access } & \multirow{3}{*}{$\begin{array}{c}\text { P. } \\
\text { value }\end{array}$} & \multirow{3}{*}{ OR } & \multirow{3}{*}{ OR $95 \% \mathrm{Cl}$} \\
\hline & \multicolumn{2}{|c|}{ Case } & \multicolumn{2}{|c|}{ Control } & & & \\
\hline & $n=162$ & $\%$ & $n=162$ & $\%$ & & & \\
\hline RH Knowledge & & & & & 0.266 & 1.28 & $0.82-1.98$ \\
\hline High & 87 & 53.7 & 77 & 47.5 & & & \\
\hline Low $^{\text {ref }}$ & 75 & 46.3 & 85 & 52.5 & & & \\
\hline $\begin{array}{l}\text { Social perception } \\
\text { of AFHS access }\end{array}$ & & & & & 0.684 & 0.89 & $0.52-1.52$ \\
\hline Positive & 33 & 20.4 & 36 & 22,2 & & & \\
\hline Negative ${ }^{\text {ref }}$ & 129 & 79.6 & 126 & 77.8 & & & \\
\hline Knowledge of & & & & & & 5.78 & \\
\hline AFHS & & & & & $<0.001$ & & 3.23- 10.34 \\
\hline Know & 68 & 42.0 & 18 & 11.1 & & & \\
\hline Not know ${ }^{\text {ref }}$ & 94 & 58.0 & 144 & 88.9 & & & \\
\hline $\begin{array}{l}\text { Opportunity to } \\
\text { access }\end{array}$ & & & & & 0.01 & 1.78 & $1.14-2.78$ \\
\hline No barrier & 83 & 51.2 & 60 & 37.0 & & & \\
\hline Had barrier ${ }^{r e f}$ & 79 & 48.8 & 102 & 63.0 & & & \\
\hline Perceived need & & & & & 0.01 & 1.77 & $1.14-2.75$ \\
\hline Need & 97 & 59.9 & 74 & 45.7 & & & \\
\hline Not need ${ }^{\text {ref }}$ & 65 & 40.1 & 88 & 54.3 & & & \\
\hline Total & 162 & 100.0 & 162 & 100.0 & & & \\
\hline
\end{tabular}


AFHS access was explained by this model. The rest proportion was explained by another factor outside the study's variables. However, based on goodness analysis of fits test with p-value 0.576 $(>0.05)$ concluded that this model had a good calibration and gave the right prediction about AFHS access.

Table 3. Multivariable Model Using Logistic Regression Analysis of AFHS Access as the Determinant.

\begin{tabular}{|c|c|c|}
\hline Variables & OR & OR $95 \% \mathrm{Cl}$ \\
\hline $\begin{array}{l}\text { Social perception } \\
\text { of accessing } \\
\text { AFHS }\end{array}$ & 0.59 & \\
\hline Positive & & $0.32-1.09$ \\
\hline Negative $e^{\text {ref }}$ & & 1 \\
\hline $\begin{array}{l}\text { Knowledge of } \\
\text { AFHS }\end{array}$ & $6.20^{* *}$ & \\
\hline Know & & $3.40-11.34$ \\
\hline Not know ref & & 1 \\
\hline $\begin{array}{l}\text { Opportunity to } \\
\text { access }\end{array}$ & $1.73^{*}$ & \\
\hline $\begin{array}{l}\text { No barrier } \\
\text { Had barrier }\end{array}$ & & $\begin{array}{c}1.06-2.80 \\
1\end{array}$ \\
\hline Percieved need & $1.88^{*}$ & \\
\hline Need & & $1.17-3.06$ \\
\hline Not need ${ }^{\text {ref }}$ & & 1 \\
\hline \multicolumn{3}{|c|}{$\begin{array}{l}\text { AIC: } 403.544 \text { BIC : } 422.44 \\
\text { Pseudo R2 : } 12.38 \%\end{array}$} \\
\hline
\end{tabular}

More importantly, this study reported low proportion of students who accessed AFHS from health professionals or peer educators at each school (15.8\%). Some previous studies in some Indonesian regions showed the prevalence of adolescents' access to AFHS ranged from $9.7 \%$ to $33.1 \%$ (Amieratunnisa and Indarjo, 2018; Handayani, 2016; Violita and Hadi, 2019; Sari et al., 2017). A previous study in Makassar district found $24.3 \%$ of students utilized adolescent reproductive health services, such as the AFHS and center for adolescent information and concelling (Violita and Hadi, 2019). Another study about access to AFHS in Miroto Primary Healthcare Center in Semarang district, Central Java found that the percentage of adolescents

The Determinants of... who accessed the service was only $12 \%$ of total respondents (Handayani and Rimawati, 2016).

In this present study, the number of students who accessed AFHS through peer educators was higher than through health professionals, meaning that the actual adolescents' access to the AFHS was low. The same problem also occurred in Other Low Middle Income Countries (LMIC), including India. In India, only a small proportion of adolescents could access the AFHS, and they were mostly girls (Dixit et al., 2017). Meanwhile, Kenya and Ethiopia had the higher proportion of adolescents' access which was $38.5 \%$ and 36\%, respectively (Motuma et al., 2016; Luvai et al., 2017). These studies brought up a critical issue of adolescent health service management that needs to be improved.

The determinant factors of AFHS access involved the absence of social barrier, such as knowledge of the AFHS, the absence of opportunity barrier and perceived demands. . This suggests that both demand factor and supply factor affected adolescents' access to AFHS (Jacobs et al., 2012). Knowledge of AFHS was the strongest determinant of AFHS utilization. Previous study in Indonesia also found knowledge of reproductive health and available service could increase $74 \%$ of the adolescents' access to the service (Violita and Hadi, 2019). In Southeast Ethiopia, a group of respondents who had heard about the service from health workers were 2.5 times more likely to utilize AFHS (Jarssa, Lodebo and Suloro, 2017). Similarly, a study in Kenya found that adolescent who heard of the Youth Friendly Reproductive Health Service (YFRHS) and knew where the service were most likely to utilized the YFRHS (Luvai, Kipmerewo and Onyango, 2017).

In the LMIC, the AFHS was not yet popular for adolescents. In Makassar City, the students mostly did not know the service (Violita and Hadi, 2019). Knowledge of the services was a demand 
to access the service (Kennedy et al., 2013). Lack of knowledge about where and what services are provided indicated demand-side barriers for adolescents to access the services (Jacobs et al., 2012). Lack of information could reduce the adolescent's awareness of maintaining health behaviour and utilizing the AFHS.

A qualitative study on adolescents' perspective of AFSH found activities initiated by the government raised awareness of what and where the service was provided (Godia et al., 2014). A literature review showed that Information Education and Counselling (IEC) outreach activities conducted by health professionals had potentials in increasing the demand. Instead of using printed IEC, promotion in mass media could result change behaviour for its ability to reach large numbers of audience (Kesterton and Cabral De Mello, 2010). The target adolescents in IEC were mostly internet literate, and thus using Internet and social media became the most promising tool to spread information about AFHS and the service provided. A literature review on a potential intervention targeting Indonesian adolescents suggested that an intervention that can improve access to reproductive health service should be delivered in an intervention package through school-based platforms, adolescent youth centres/peer education and technology-based platforms (Oddo, Roshita and Rah, 2019). Promotion of AFHS through health providers, peer educators and electronic media have to be done to eliminate the knowledge of AFHS barrier.

Another demand factor that affected access to AFHS was perceived need for the service. In this study, the adolescents who perceived need for the services were likely to access AFHS, and the same thing happened in South Ethiopia(Cherie, Tura and Teklehaymanot, 2015). In Finland, adolescents who perceived need for school health nurses likely reported difficulties in accessing the service (Kivimäki et al., 2019). Adolescents who need for support would seek for the service if the AFHS available in their community met their needs (Godia et al., 2014). From the perceived need questionnaires data showed that many adolescents received health information by searching information through social media and the Internet, but many of them were not convinced after reading some health information and asked health professionals to confirm the validity of the information. Having good access to sexual and reproductive health rights through life skill (Sexual Reproductive Health $(\mathrm{SRH})$ information, negotiation skill and literacy training) has always been associated with better SRH outcomes and access to health service (Svanemyr et al., 2015).

In spite of available service and demands on the service, barriers from the supply-side factor may hinder the access. This present study revealed free access to the service did not make the respondents access the service because the service was only open during school hours. Students who perceived opportunity cost to leave the school outweighing the benefits of accessing the service would postpone to access the AFHS. The AFHS did not comply with the standards of WHO which said the service whould be open at convenient working hours (World Health Organization, 2012). Godia's research found a lot of adolescents suggested the service to be open until evening and in public holiday and weekend (Godia et al., 2014).

Peer educators can reduce opportunity barriers of AFHS access since students probably met them during school break time at schools. Peer educators could only support peer counselling and information, but they were vital for providing more information and service from health professionals in a health care facility. They became outreach workers to reduce opportunity barriers. Redefining the role of peer educators was an effective way in optimizing peer educators' strategy (Chandra-Mouli, Lane and Wong, 2015). Further study is required to confirm the 
effectiveness of peer educators for bridging the school and the AFHS.

Moreover, this present study found the students could not identify the presence of peer educators at their schools. Information of the peer educators was only distributed to a small group of students. A qualitative study on the effectivity of peer education suggested that the selection of peer educators plays a significant role in the success of peer education program. Peer educators should come from popular groups chosen by their friends (Karaca, Akkus and Sener, 2018). Besides, peer educators also should have listening skills and communication skills to deliver health information. Furthermore, they have to have potential leadership characteristics for being role models, who have time, energy, and willingness to work voluntarily (Bilgiç and Günay, 2014). Such requirements should be taken into account in selecting students as peer educators. Moreover, the health officers could optimalize their roles in communicating health information to students through scheduled monitoring.

Besides, demographics factor that significantly influenced access to AFHS was sex. The research uncovered that girls mostly utilized the AFHS since most of the health officers were female. Respondents who asked health professional about reproductive health information were dominated by girls (Arifah and Sharfina, 2019). Another study found the health officers in the AFHS were mostly female (Afrianti and Tahlil, 2017). Girls were more comfortable to speak with female health officer. A qualitative study in Nepal discovered that male and female adolescents considered the gender of the health officers when accessing the program. In this case, male adolescents were more susceptible to have health problems for their reluctance to access health service. Whereas, some research found boys had higher tendencies to engage in some risky health behaviour, such as, risky sexual behaviour, smoking and drug and alcohol consumption
(Sawyer et al., 2012; Kreager et al., 2016). The multicollinearity analysis showed that boys lacked knowledge probably because more girls became peer educators than boys. A study on communication model between boys showed that they did not communicate their health, especially sensitive reproductive health issue, with others. They chose to browse information online rather than speaking directly to their peers (Kurniasih, 2018). A specific approach to encourage and educate boys about the service should be developed to make sure the AFHS was accessible to all gender.

In contrast to other variables, knowledge of reproductive health was not proven to be a significant determinant of access. This finding was different from the previous study in Nepal, showing adolescents who had poor sexual and reproductive health literacy had the high likelihood of poor knowledge of the sexual and reproductive health service (Pandey, Seale and Razee, 2019). Nowadays, adolescents searched for information on the Internet, resulting in a good collection of information from various sources. However, literate adolescents in health information will not believe in the validity of information, and thus they will still ask professionals to confirm information they had.

Moreover, social perception of accessing the AFHS did not affect adolescents to access the AFHS as well. Adolescents who perceived others' opinion about accessing AFHS as an embarrassing action and taboo rarely accessed the AFHS. Similar result was found in Violita's and Hadi's research (2019), which found perceived barrier was not associated with the utilization of reproductive health service. Conversely, a study in Nepal found that perceived barrier determined adolescents' access to AFHS. Barriers to access AFHS involved lack of confidentiality of the service and distance to health facilities. Another factor that affect adolescents' decision to utilize the service was their peers, yet their social 
environment and people's perception (Bam et al., 2015).

All in all, this study had limitations in terms of the selection of case and control group samples. There was a significant difference in the respondents' characteristics, such as age, gender and education level between the case and control groups. The proportion of female respondents significantly affected the level of access to the AFHS by the control group and case group. Moreover, the sampling technique for the control group should be examined further in future research for collecting more compatible respondents.

\section{CONCLUSION}

Overall, adolescents had insufficient knowledge of AFHS. Some determinant factors of AFHS access included the absence of social barriers, such as knowledge of AFHS, absence of opportunity barrier and perceived need for the service. To improve the access to the service, promotion on social media, internet, and through peer educators should be done. By far, peer educators could increase the access to AFHS by reducing the opportunity barrier. School and primary healthcare centers should set an active referral system to improve the access.

\section{CONFLICT OF INTEREST}

Authors declared that there was no conflict of interest in this study.

\section{REFERENCES}

Afrianti, N. and Tahlil, T. (2017) 'Analisis Implementasi Program Pelayanan Kesehatan Peduli Remaja (PKPR)', jurnal.unsyiah.ac.id, 5(2), pp. 1527.

Amieratunnisa, A. and Indarjo, S. (2018) 'Implementasi Program Pelayanan Kesehatan Peduli Remaja', Higeia Journal of Public Health Research and Development, 2(2), pp. 171180.
Arifah, I. and Sharfina, M. F. (2019) 'Hambatan Akses Informasi Kesehatan Reproduksi Pada Mahasiswa Kesehatan Universitas Muhammadiyah Surakarta', Jurnal Kesehatan, 11(2), pp. 65-74. doi: 10.23917/jurnal\%20kesehatan.v11i 2.7532 .

Bam, K. et al. (2015) 'Perceived Sexual and Reproductive Health Needs and Service Utilization among Higher Secondary School Students in Urban Nepal', American Journal of Public Health Research, 3(2), pp. 36-45. doi: 10.12691/ajphr-3-2-1.

Bilgiç, N. and Günay, T. (2014) 'A method for supporting smoking cessation in adolescents: Peer education', Turkish Thoracic Journal, 13, pp. 102-105. doi: 10.5152/ttd.2013.27.

Chandra-Mouli, V., Lane, C. and Wong, S. (2015) 'What does not work in adolescent sexual and reproductive health: A review of evidence on interventions commonly accepted as best practices', Global Health Science and Practice, 3(3), pp. 333-340. doi: 10.9745/GHSP-D-1500126.

Centre for Data and Information of Indonesian Ministry of Health (2018) Situasi Kesehatan Reproduksi, Situasi Kesehatan Reproduksi. Available at: https://pusdatin.kemkes.go.id/folder/ view/01/structure-publikasi-pusdatininfo-datin.html (Accessed: 1 July 2020).

Cherie, N., Tura, G. and Teklehaymanot, N. (2015) 'Reproductive health needs and service utilization among youths in West Badewacho Woreda, Hadiya Zone, South Ethiopia', Journal of Public Health and Epidemiology, 7(4), pp. 145153. doi: 10.5897/JPHE2014.0700.

Dixit, G. T. et al. (2017) 'Adolescent friendly health services: where are we actually standing?', International Journal Of Community Medicine And Public Health, 4(3), pp. 820824. doi: 10.18203/23946040.ijcmph20170765. 
Friskarini, K. and Manalu, H. S. (2016) 'Implementasi Program Pelayanan Kesehatan Peduli Remaja (PKPR) Di Tingkat Puskesmas DKI Jakarta', Jurnal Ekologi Kesehatan, 15(1), pp. 66-75. doi: 10.22435/jek.v15i1.4957.66-75.

Godia, P. M. et al. (2014) 'Young people's perception of sexual and reproductive health services in Kenya', BMC Health Services Research. BioMed Central Ltd., 14(172), pp. 1-13. doi: 10.1186/1472-6963-14-172.

Handayani, S. and Rimawati, E. (2016) 'Pemanfaatan Layanann PKPR Oleh Remaja di Wilayah Kerja Puskesmas Miroto Semarang', Jurnal Keperawatan dan Kesehatan Masyarakat, 2(4), pp. 93-97.

Jacobs, B. et al. (2012) 'Addressing access barriers to health services: An analytical framework for selectingappropriate interventions in low-income Asian countries', Health Policy and Planning, 27(4), pp. 288300. doi: 10.1093/heapol/czr038.

James, S. et al. (2018) 'Assessment of adolescent and youth friendly services in primary healthcare facilities in two provinces in South Africa', BMC Health Services Research. BMC Health Services Research, 18(809), pp. 1-10. doi: 10.1186/s12913-018-3623-7.

Jarssa, A. G., Lodebo, T. M. and Suloro, J. A. (2017) 'Youth friendly sexual and reproductive health services utilization and associated factors among school youths in Goba town, bale zone, Southeast Ethiopia', European Journal of Biomedical and Pharmaceutical sciences, 4(3), pp. 335-346.

Karaca, A., Akkus, D. and Sener, D. K. (2018) 'Peer Education from the Perspective of Peer Educators', Journal of Child and Adolescent Substance Abuse. Routledge, 27(2), pp. 76-85. doi: 10.1080/1067828X.2017.1411303.

Kennedy, E. C. et al. (2013) "Be kind to young people so they feel at home": A qualitative study of adolescents' and service providers' perceptions of youth-friendly sexual and reproductive health services in Vanuatu', BMC Health Services Research, 13(455), pp. 1-12. doi: 10.1186/1472-6963-13-455.

Kesterton, A. J. and Cabral De Mello, M. (2010) 'Generating demand and community support for sexual and reproductive health services for young people: A review of the literature and programs', Reproductive Health, 7(25), pp. 112. doi: 10.1186/1742-4755-7-25.

Kivimäki, H. et al. (2019) 'Access to a school health nurse and adolescent health needs in the universal school health service in Finland', Scandinavian Journal of Caring Sciences. Blackwell Publishing Ltd, 33(1), pp. 165-175. doi: $10.1111 /$ scs. 12617.

Kreager, D. A. et al. (2016) 'The double standard at sexual debut: Gender, sexual behavior and adolescent peer acceptance', Sex Roles, 75(7), pp. 377-392.

Kurniasih, N. (2017) 'Model of Adolescent Reproductive Health Information Dissemination in Bandung Indonesia', in Implementation of Climate Change Agreement to Meet Sustainable Development Goals (ICPSUAS 2017). Surabaya: Atlantis Press, pp. 206-209. Available at: https://download.atlantis-

press.com/article/25891283.pdf.

Luvai, N. U., Kipmerewo, M. and Onyango, K. O. (2017) 'Utilization of Youth Friendly Reproductive Health Services Among the Youth Bureti Sub County in Kenya', European Journal of Pharmaceutical and Medical Research, 4(4), pp. 203212.

Motuma, A. et al. (2016) 'Utilization of youth friendly services and associated factors among youth in Harar town, east Ethiopia: A mixed method study', BMC Health Services Research. BioMed Central Ltd., 16(272), pp.1-10. doi: 10.1186/s12913-016-1513-4.

Oddo, V. M., Roshita, A. and Rah, J. H. (2019) 'Potential interventions targeting adolescent nutrition in 
Indonesia: A literature review', Public Health Nutrition. Cambridge University Press, 22(1), pp. 15-27. doi: $10.1017 / S 1368980018002215$.

Pandey, P. L., Seale, H. and Razee, H. (2019) 'Exploring the factors impacting on access and acceptance of sexual and reproductive health services provided by adolescent-friendly health services in Nepal', PLOS ONE. Edited by S. Federici. Public Library of Science, 14(8), pp. 1-19. doi: 10.1371/journal.pone.0220855.

Patton, G. C. et al. (2009) 'Global patterns of mortality in young people: a systematic analysis of population health data', The Lancet, 374(9693), pp. 881-892. doi: 10.1016/S0140-6736(09)60741-8.

Sari, N. D., Musthofa, S. B. and Widjanarko, B. (2017) 'Hubungan Partisipasi Remaja Dalam Kegiatan Pelayanan Kesehatan Peduli Remaja (Pkpr) Dengan Pengetahuan Dan Persepsi Mengenai Kesehatan Reproduksi Di Sekolah Menengah Pertama Wilayah Kerja Puskesmas Lebdosari', Jurnal Kesehatan Masyarakat (e-Journal), 5(5), pp. 1072-1080.

Sawyer, S. M. et al. (2012) 'Adolescence: A foundation for future health', The Lancet, 379(9826), pp. 1630-1640. doi: $10.1016 / \mathrm{S} 0140-$ 6736(12)60072-5.

Situmorang, A. (2016) 'Pelayanan Kesehatan Reproduksi Remaja di Puskesmas: Isu dan Tantangan', Jurnal Kependudukan Indonesia, 6(2), pp. 21-32. Available at: http://ejurnal.kependudukan.lipi.go.i d/index.php/jki/article/view/92/138.

Surakarta District Health Office (2016)
Profil Kesehatan Kota Surakarta Tahun 2015. Surakarta.

Svanemyr, J. et al. (2015) 'Creating an enabling environment for adolescent sexual and reproductive health: a framework and promising approaches', Journal of adolescent health, 56(1), pp. S7-S14. Available at:

https://www.sciencedirect.com/scien ce/article/pii/S1054139X14004236

(Accessed: 5 June 2020).

UNICEF (2011) Opportunity in Crisis: Preventing HIV from early adolescence to young adulthood. New York. Available at: https://www.unicef.org/publications/fil es/Opportunity_in_Crisis-

Report_EN_052711.pdf.

Violita, F. and Hadi, E. N. (2019) 'Determinants of adolescent reproductive health service utilization by senior high school students in Makassar, Indonesia', BMC Public Health. BMC Public Health, 19(286), pp. 1-7. doi: 10.1186/s12889-019-6587-6.

Winangsih, R., Kurniati, D. P. Y. and Duarsa, D. P. (2015) 'Faktor Predisposisi, Pendukung dan Pendorong Pemanfaatan Pelayanan Kesehatan Peduli Remaja di Kuta Selatan', Public Health and Preventive Medicine Archive, 3(5), p. 133-140. doi: 10.15562/phpma.v3i2.100.

World Health Organization (2012) Making health services adolescent friendly. Switzerland: World Health Organization.

World Health Organization (2018) WHO methods and data sources for global burden of disease estimates 20002016. Geneva. 